\title{
Dental Abscess Due to Streptococcus anginosus
}

\section{Streptococcus anginosus'a Bağlı Diş Apsesi}

\author{
Ergin Çiftçil',(i, \\ ${ }^{1}$ Division of Pediatric Infectious Diseases, Department of Pediatrics, Ankara University School of Medicine, Ankara, Turkey \\ ${ }^{2}$ Clinic of Pediatric Infectious Diseases, Okmeydani Training and Research Hospital, Istanbul, Turkey
}

\begin{abstract}
Cite this article as: Çiftçi E, Uslu AM, Karbuz A. Dental abscess due to Streptococcus anginosus. J Pediatr Inf 2019;13(4):e183.
\end{abstract}
A 16-year-old male patient presented with fever and painful swelling on his right cheek and under the chin, which started 5 days earlier and progressed gradually. His past and ancestral histories were unremarkable. In the physical examination, on the right side, there was a painful, fluctuating, reddening mass with a diameter of about $5 \mathrm{~cm}$, which was consistent with the abscess formation, covering the corpus mandible and both supra and submandibular regions. The patient had a large number of dental caries in his mouth, and an appearance consistent with tooth abscess in the lower right side, and otorrhea in the right ear. Laboratory tests were as follows: white blood cell count was $24.000 / \mathrm{mm}^{3}$, hemoglobin level was $14 \mathrm{~g} / \mathrm{dL}$, platelet count was $438.000 / \mathrm{mm}^{3}$, C-reactive protein level was 30 $\mathrm{mg} / \mathrm{L}$. Superficial ultrasonography revealed a $59 \times 26 \mathrm{~mm}$ abscess formation in the right submandibular area and edema in the surrounding structures. The patient was accepted as dental abscess and suppurative otitis media. Cefoperazone-sulbactam and clindamycin were started intravenously. Streptococcus anginosus was cultured in the culture of approximately 10 $\mathrm{mL}$ of purulent abscess material which was surgically drained. Pseudomonas aeruginosa was isolated from the ear discharge material. Mandibular osteomyelitis was excluded by magnetic resonance imaging. The lesion gradually regressed. Parenteral antibiotic therapy was continued for 14 days and the patient was discharged for another 7 days of oral amoxicillin clavulonate treatment. Immunological tests were normal. After discharge, he was referred to the dentist for dental caries.

Dental abscess is a common condition. The course of infection varies depending on the host factor, bacterial virulance, and regional anatomy. The spread of a dental abscess may result in significant morbidity and mortality. Anaerobic cocci, definitive anaerobes such as Prevotella, Fusobacterium species, viridans group streptococci and facultative anaerobes such as S. anginosus may cause acute tooth abscesses. Polymicrobial infection is also common. While most localized dental abscesses respond well to appropriate antimicrobial therapy, surgical intervention may be required in some cases.

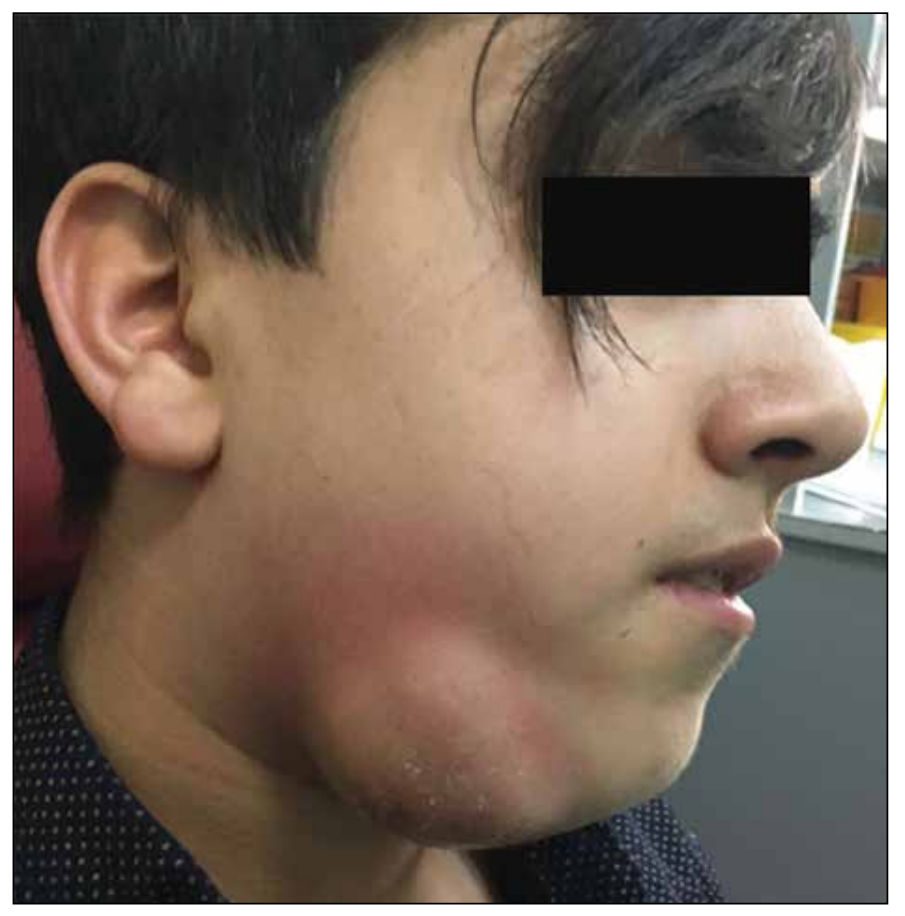

\footnotetext{
Correspondence Address/Yazışma Adresi

Ergin Çiftçi

Ankara Üniversitesi Tıp Fakültesi,

Çocuk Sağlığı ve Hastalıkları Anabilim Dalı,

Çocuk Enfeksiyon Hastalıkları Bilim Dalı,

Ankara-Türkiye

E-mail: erginciftci@gmail.com
}

Received: 12.12 .2019
@Copyright 2019 by Pediatric Infectious Diseases and Immunization Society. Available online at www.cocukenfeksiyon.org 